\title{
ЗАБЕЗПЕЧЕНІСТЬ СИСТЕМИ ОХОРОНИ ЗДОРОВ'Я МЕДИЧНИМИ ЗАКЛАДАМИ ТА МЕДПЕРСОНАЛОМ
}

\author{
ДВНЗ «Тернопільський державний медичний університет імені І.Я. Горбачевського МОЗ України»
}

\begin{abstract}
Мета: виявити особливості забезпеченості системи охорони здоров'я медперсоналом, медичними закладами та устаткуванням, вивчити сучасний стан та тенденції в охороні здоров'я у світі та в Україні.

Матеріали і методи. У дослідженні використано статистичні дані ВООЗ щодо стану охорони здоров'я у країнах світу та показники ресурсів охорони здоров'я в Україні; застосовувалися методи статистичного аналізу, синтезу та дедукції для виявлення забезпеченості медперсоналом, медичними закладами та устаткуванням.

Результати. Встановлено, що у сфері охорони здоров'я в Україні і світі спостерігаються наступні тенденції: зменшення загальної кількості лікарняних ліжок при зростанні інтенсивності їх роботи; збільшення кількості спеціалізованих відділень; зростання ваги невідкладної медичної допомоги.

Висновки. Проведений аналіз дозволяє робити прогноз щодо необхідності тих чи інших видів медичних послуг та відповідних змін в організації охорони здоров'я.

КЛЮчОВІ СЛОВА: охорона здоров'я, медичний заклад, медперсонал.
\end{abstract}

Лікарні та медичні працівники є центральними елементами системи охорони здоров'я. Від них залежить рівень доступу до медико-санітарної допомоги в цілому та спеціалізованих послуг зокрема. Фахівці лікарень - це професійна еліта. Нові методи лікування, технологічні й фармацевтичні відкриття запроваджують спочатку в лікарнях, тож останні відіграють провідну роль у системі охорони здоров'я.

Важливе значення мають дані про ресурси, доступні системам охорони здоров'я, такі як робоча сила (лікарі, медсестри, акушерки, інші працівники охорони здоров'я), інфраструктура (лікарні, лікарняні і психіатричні ліжка), медичні технології та прилади (променевої терапії, комп'ютерної томографії, мамографії), тому що ця інформація дає владі можливість визначити, як найкраще задовольнити потреби населення в охороні здоров'я [2].

Мета дослідження: виявити особливості забезпеченості системи охорони здоров'я медперсоналом, медичними закладами та устаткуванням, вивчити сучасний стан та зміни у забезпеченості медичними закладами та медперсоналом систем охорони здоров'я у світі та в Україні.

Матеріали і методи. У дослідженні використано актуальні статистичні дані ВООЗ щодо стану охорони здоров'я у країнах світу та показники ресурсів охорони здоров'я в Україні, методи статистичного аналізу, синтезу та дедукції для виявлення забезпеченості медперсоналом, медичними закладами та устаткуванням.

Результати дослідження та їх обговорення. Показник забезпеченості лікарняними ліжками певною мірою свідчить про доступність стаціо- нарної медичної допомоги. Джерелом статистики забезпеченості лікарняними ліжками переважно $є$ поточна адміністративна звітність, але в цих цифрах не завжди враховано приватний сектор. Показник забезпеченості психіатричними ліжками дає оцінку потенціалу лікування серйозних психічних розладів, які вимагають стаціонарної медичної допомоги.

У табл. 1 наведені дані щодо забезпеченості країн із різним рівнем доходів медичними закладами і медперсоналом [6]; показники забезпеченості медперсоналом враховують активних працівників охорони здоров'я, тобто тих, які є учасниками ринку праці в охороні здоров'я. Слід зважати на те, що наведені дані можуть бути занижені або завищені у випадках, коли неможливо визначити, чи входять у цю цифру працівники охорони здоров'я приватного сектору та чи є помилки подвійного обліку при працевлаштуванні за сумісництвом.

Із таблиці 1 видно, що середньостатистичні показники забезпеченості медичними закладами і медперсоналом переважно вищі у країнах з вищим рівнем доходів. Наведені дані свідчать, що кількість лікарів, стоматологічного персоналу та психіатричних ліжок в Україні вища, лікарняних ліжок - значно вища, навіть за відповідні показники країн із високим рівнем доходів, а кількість психіатрів відповідає показникові останніх. Забезпеченість сестринським та акушерським персоналом в Україні дещо нижча, ніж у країнах із високим рівнем доходів, що, поряд із даними про забезпеченість лікарськими кадрами, підтверджує згадані нами тенденції до зростання у розвинених країнах частки закладів, що спеціалізуються на сестринському догляді. На жаль, дані про середньостатистичний показ- 
Таблиця 1. Забезпеченість медичними закладами і медперсоналом у країнах із різним рівнем доходів (на 10000 населення)

\begin{tabular}{|c|c|c|c|c|c|c|c|c|}
\hline Країна & 跑 & 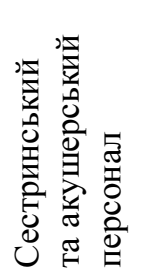 & 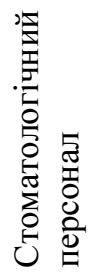 & 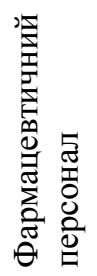 & 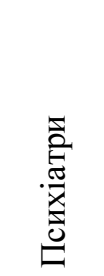 & 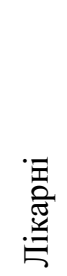 & 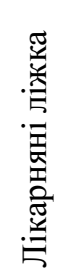 & 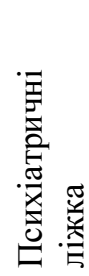 \\
\hline Україна & 35,3 & 76,0 & 6,8 & 0,4 & 1,0 & 0,4 & 90 & 9,4 \\
\hline Країни з низьким рівнем доходів & 2,4 & 5,4 & 0,3 & 0,5 & $<0,05$ & 0,8 & 21 & 0,2 \\
\hline $\begin{array}{l}\text { Країни з доходами, нижчими } \\
\text { за середні }\end{array}$ & 7,8 & 17,8 & 1,2 & 4,2 & 0,1 & - & 10 & 0,6 \\
\hline $\begin{array}{l}\text { Країни з доходами, вищими } \\
\text { за середні }\end{array}$ & 15,5 & 25,3 & - & 3,1 & 0,2 & - & 32 & 2,2 \\
\hline Країни з високим рівнем доходів & 29,4 & 86,9 & 5,8 & 8,4 & 1,0 & - & 54 & 8,3 \\
\hline
\end{tabular}

ник кількості лікарень неповні, що робить неможливим їх порівняння. Подібне випливає із порівняння даних забезпеченості різних регіонів медичними закладами і медперсоналом [6].

Натомість, якщо порівняти подані в табл. 2 дані системи охорони здоров'я України та першої десятки країн у складеному Всесвітньою організацією охорони здоров'я у 2000 році рейтингу провідних систем охорони здоров'я', то можемо виявити, що майже всі показники, які характеризують систему охорони здоров'я України, не $є$ ані нижчими, ані вищими за відповідні індикатори передових з погляду медицини країнчленів ВООЗ: лікарі (найнижчий показник у Сінгапуру - 19,2, найвищий показник у Сан-Марино 51,3, Україна - 35,3), сестринський та акушерський персонал (Іспанія - 50,8, Японія - 115, Україна - 76), стоматологічний персонал (Оман 2,6, Японія - 7,9, Україна - 6,8), фармацевтичний персонал (Сінгапур - 3,9, Японія - 21,5, Україна - 0,4, показник, що може бути зумовлений похибками статистичного обліку), психіатри (Оман - 0,2, Франція - 2,2, Україна - 1), лікарні (Сінгапур - 0,5, Сан-Марино - 3,2, Україна - 0,4), лікарняні ліжка (Оман - 17, Японія - 137, Україна 90), психіатричні ліжка (Італія - 1,1, Японія - 27,8, Україна - 9,4) [6]. Наочною є велика ресурсо-

1 Рейтинг досягнень і продуктивності систем охорони здоров'я усіх країн-членів ВООЗ, упорядкований Всесвітньою організацією охорони здоров'я на основі восьми показників (таких як загальний рівень здоров'я населення, нерівність населення за ознакою здоров'я, загальний рівень дієвості системи охорони здоров'я, розподіл дієвості серед населення з різним економічним становищем, розподіл фінансового тягаря системи охорони здоров'я серед населення тощо) та опублікований у Доповіді про стан охорони здоров'я у світі за 2000 рік. Рейтинг унікальний та після 2000 року Всесвітньою організацією охорони здоров'я повторно не укладався у зв'язку із складністю та об'ємністю розрахунків. ємність системи охорони здоров'я Японії - країни, що посідає десяту сходинку цього рейтингу, яка займає передові позиції за п'ятьма із наведених показників.

У Європі протягом останніх десятиліть лікарні зазнали значних змін. Одні фактори зменшили тривалість перебування хворого у лікарні, інші її збільшили. Важливу роль відіграє старіння населення, тому що старші люди лягають у лікарню частіше і на довше. Змінюється епідеміологічна ситуація (з'являються нові хвороби, а вже відомі мають інший перебіг), виникають захворювання, спричинені способом життя, харчуванням, тютюнопалінням. Завдяки розвитку медицини і технологій (пересадка органів, лікування раку тощо) можливості лікування зростають, і тепер є змога надавати медичну допомогу ширшим категоріям хворих. Малоінвазивні методи зменшили операційний ризик, а сучасні ліки скоротили терміни госпіталізації. Водночас деякі ліки спричинили збільшення тривалості перебування у лікарні, бо дали змогу лікувати хвороби, які раніше вважалися невиліковними.

Протягом останнього півстоліття зросла концентрація дорогих послуг, таких як комп'ютерна томографія. У розвинених країнах спостерігається збільшення витрат на охорону здоров'я взагалі та на лікарні зокрема. Так, частка загальних витрат на охорону здоров'я у ВВП зросла в середньому у 2-2,5 разу, а витрати на лікарні становлять приблизно 50\% усіх витрат на охорону здоров'я. Нові країни-члени ЄС зараз витрачають на охорону здоров'я в середньому 7 \% ВВП, а дві третини цих коштів йдуть на лікарні.

Розвинені європейські країни, США, Канада, Австралія роблять спроби скоротити кількість лікарняних ліжок і терміни перебування хворих у лікарнях, перепрофілювати лікарні та перекласти деякі їхні функції на інші заклади. На лікарні 
Таблиця 2. Забезпеченість медичними закладами і медперсоналом провідних систем охорони здоров'я та України (на 10000 населення)

\begin{tabular}{|c|c|c|c|c|c|c|c|c|c|}
\hline Країна & 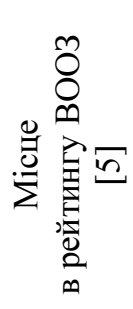 & 离 & 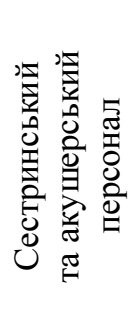 & 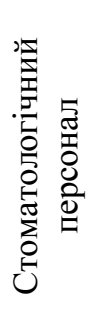 & 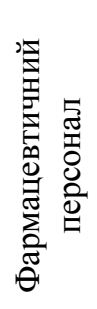 & 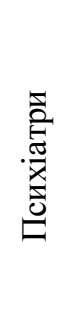 & 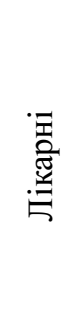 & 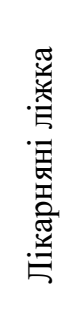 & 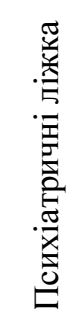 \\
\hline Франція & 1 & 31,8 & 93 & 6,6 & 11 & 2,2 & - & 64 & 9,5 \\
\hline Італія & 2 & 40,9 & - & - & - & 0,8 & 2,1 & 34 & 1,1 \\
\hline Сан-Марино & 3 & 51,3 & 88,9 & - & 7,2 & 1,6 & 3,2 & 38 & - \\
\hline Андорра & 4 & - & - & - & - & 0,7 & - & 25 & 1,4 \\
\hline Мальта & 5 & 35 & 70,9 & 4,5 & 11,6 & 0,3 & 0,9 & 48 & 14,5 \\
\hline Сінгапур & 6 & 19,2 & 63,9 & 3,3 & 3,9 & 0,3 & 0,5 & 20 & 4,2 \\
\hline Іспанія & 7 & 37 & 50,8 & - & 10,3 & 0,9 & 1,6 & 31 & 4,3 \\
\hline Оман & 8 & 22,2 & 50 & 2,6 & 10,7 & 0,2 & 1,3 & 17 & 0,3 \\
\hline Австрія & 9 & 48,3 & 79,1 & 5,7 & 6,9 & 2 & - & 76 & 4 \\
\hline Японія & 10 & 23 & 115 & 7,9 & 21,5 & 1 & - & 137 & 27,8 \\
\hline Україна & 79 & 35,3 & 76 & 6,8 & 0,4 & 1 & 0,4 & 90 & 9,4 \\
\hline
\end{tabular}

й надалі покладається завдання лікувати хворих, які потребують спеціалізованої, інтенсивної медичної допомоги, розширеної діагностики, передових методів лікування.

Крім того, важливим якісним показником матеріальної забезпеченості системи охорони здоров'я $є$ наявність медичних приладів та установок. Медичні прилади незамінні у профілактиці, діагностиці та лікуванні захворювань, а також реабілітації та паліативній допомозі. На сьогодні забезпеченість установками для променевої терапії, комп'ютерної томографії та мамографії $€$ індикатором наявності дорогого високоякісного обладнання для діагностичної томографії та променевої терапії раку. Наведені у табл. 3 дані ілюструють значне відставання системи охорони здоров'я України у сфері матеріального забезпечення $[1 ; 6]$.

Таблиця 3. Забезпеченість медичними установками провідних систем охорони здоров'я та України

\begin{tabular}{|c|c|c|c|c|}
\hline Країна & 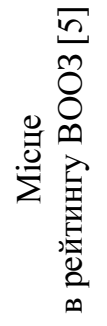 & 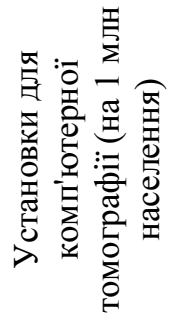 & 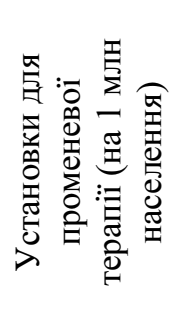 & 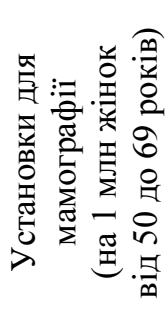 \\
\hline Франція & 1 & & 7,5 & - \\
\hline Італія & 2 & - & 6,4 & - \\
\hline Сан-Марино & 3 & 31,8 & 0 & 229,1 \\
\hline Андорра & 4 & - & - & - \\
\hline Мальта & 5 & 9,3 & 4,7 & 99,7 \\
\hline Сінгапур & 6 & 8,9 & 3,5 & 127,6 \\
\hline Іспанія & 7 & 13,9 & 4,2 & - \\
\hline Оман & 8 & 6,9 & 0,6 & 149,8 \\
\hline Австрія & 9 & 28,5 & 5,4 & - \\
\hline Японія & 10 & 101,2 & 7,2 & 227,3 \\
\hline Україна & 79 & 1,3 & 2,4 & - \\
\hline
\end{tabular}


Зменшення кількості ліжок супроводжується скороченням тривалості перебування хворого у лікарні: після інтенсивної терапії пацієнти переходять у заклади, що забезпечують медсестринський догляд, або отримують медичну допомогу вдома. Цьому сприяють нові стандарти медичної допомоги, такі як скорочення післяопераційного перебування у стаціонарі, нові технології, зростання кількості амбулаторних закладів. У країнах ЄС середню тривалість перебування в стаціонарі скорочено з 12 до 5-7 днів, жінок після пологів без ускладнень - до 24 годин, а туберкульоз лікують амбулаторно; в Україні у середньому ці терміни становлять відповідно 12-14 днів, 8 днів та багато місяців перебування у лікарні [4].

Однак не може існувати універсальних рекомендацій щодо оптимальної кількості ліжок, єдиних для різних соціальних, економічних та екологічних середовищ. У країнах, що розвиваються, в яких лікарняні заклади виконують також медико соціальні функції, кількість лікарняних ліжок неможливо знизити до такого ж рівня, як у розвинених країнах, де лікарні надають переважно спеціалізовану медичну допомогу при гострих захворюваннях [3].

Процеси оптимізації у різних країнах відбувалися по-різному: скорочення числа ліжок на 7\% без зменшення кількості лікарень у Німеччині в 90-і роки, закриття третини стаціонарів у Великобританії та Ірландії, відкриття медичних закладів іншого типу в Бельгії, Данії та Франції. Зміна структури медичної допомоги - один із шляхів до перепрофілювання лікарень. Так, у Великобританії скорочення кількості лікарняних і психіатричних ліжок супроводжується збільшенням кількості закладів, що надають медичні послуги в умовах, наближених до домашніх. Таким чином, розвиток альтернативних форм довгострокової медичної допомоги дозволяє скеровувати певних пацієнтів у більш придатні для них заклади. Розвиток соціальних служб і нові препарати допомагають багатьом пацієнтам добре адаптуватися до навколишнього середовища. Водночас у лікарнях перебувають важкохворі, що вимагає іншої підготовки медсестер і обслуговуючого персоналу. Скорочення кількості ліжок має також і негативні наслідки: передчасне виписування з лікарні, що іноді призводить до повторної госпіталізації, зростання часу очікування пацієнтів на процедури.

Здійснювати планування охорони здоров'я, навіть обґрунтоване, дуже складно, адже лікарня охоплює своєю діяльністю великий період часу. Можливим є прогнозування демографічних процесів і розвитку певних захворювань. Наприклад, що зростання паління серед підлітків через 30 років призведе до росту захворюваності на рак легенів; що позитивні зміни у раціоні харчування жителів певного регіону через декілька років спричинять зниження захворюваності на серцевосудинні захворювання. Маючи таку інформацію, можна передбачити, з якими захворюваннями пацієнти будуть звертатися у лікарні, і провести відповідні кількісні та якісні зміни медичних послуг, штатних розписів тощо. Натомість складніше було б передбачити наслідки політичних, економічних та технологічних змін.

\section{Висновки}

Таким чином, сучасні тенденції дають змогу зробити такі прогнози: у майбутньому загальна кількість лікарняних ліжок зменшуватиметься, але зростуть обсяг і масштаби надання медичної допомоги; спеціалізовані лікарні прийматимуть переважно пацієнтів із серйозними захворюваннями та з шансами на одужання; збільшиться кількість спеціалізованих відділень; зросте вага невідкладної медичної допомоги; операційні відділення будуть використовуватися для більш складних операцій; буде потрібно більше ліжок для інтенсивної терапії та післяопераційного догляду, і менше - для пацієнтів із гострими захворюваннями у традиційному сенсі; легших пацієнтів, що потребуватимуть незначної медичної допомоги, лікуватимуть за межами лікарень.

Перспективи подальших досліджень полягають у детальному вивченні кількісних і якісних складників системи охорони здоров'я та їх системного поєднання для прогнозування їх оптимального співвідношення.

\section{Список літератури}

1. Литвинова О. Н. Економічні питання охорони здоров'я України / О. Н. Литвинова, Л. М. Романюк, В. С. Коломийчук // Вісн. соц. гігієни та орг. охорони здоров'я України. - 2012. - № 1. - С. 95-97.

2. Литвинова О. Н. Науково-технічний прогрес як основа переродження системи охорони здоров'я / О. Н. Литвинова, Н. О. Теренда // Вісн. соц. гігієни та орг. охорони здоров'я України. - 2013. - № 3. - С. 64-67.

3. Нормативи потреби населення в ліжках / О. М. Голяченко, А. Г. Шульгай, Н. Я. Панчишин [та ін.] // Вісн. соц. гігієни та орг. охорони здоров'я України. - 2013. - № 4. - С. 5-8.

4. Показники здоров'я населення та використання ресурсів охорони здоров'я в Україні за 2013 рік : дов. / ЦМС МОЗ України ; відпов. ред. М. В. Голубчиков; відпов. уклад. М.В. Голубчиков. - К., 2014.

5. The World Health Report 2000, press release, 21 June 2000 [Electronic resource] / World Health Organization. Access mode : http://www.who.int/whr/2000/en/press_release.htm> (3 November 2000). - Title from screen.

6. World Health Statistics 2014. - Geneva : WHO Press., 2014. [Electronic resource]. Access mode : http://apps.who.int/ iris/bitstream/10665/112738/1/9789240692671_eng.pdf. - Title from screen. 


\section{ОБЕСПЕЧЕННОСТЬ СИСТЕМЫ ЗДРАВООХРАНЕНИЯ МЕДИЦИНСКИМИ УЧРЕЖДЕНИЯМИ}

\section{И МЕДПЕРСОНАЛОМ}

Ю.Н. Петрашик

ГВУЗ «Тернопольский государственный медицинский университет имени И.Я. Горбачевского МЗ Украины»

Цель: выявить особенности обеспеченности системы здравоохранения медперсоналом, медицинскими учреждениями и оборудованием, изучить современное состояние и тенденции в здравоохранении в мире и в Украине.

Материалы и методы. В исследовании использованы статистические данные ВОЗ о состоянии здравоохранения в странах мира и показатели ресурсов здравоохранения в Украине; применялись методы статистического анализа, синтеза и дедукции для выявления обеспеченности медперсоналом, медицинскими учреждениями и оборудованием.

Результаты. Установлено, что в сфере здравоохранения в Украине и мире наблюдаются следующие тенденции: уменьшение общего количества стационарных коек при увеличении интенсивности их работы; увеличение количества специализированных отделений; увеличение веса неотложной медицинской помощи.

Выводы. Проведенный анализ позволяет прогнозировать необходимость тех или иных видов медицинских услуг и соответствующих изменений в организации здравоохранения.

КЛЮЧЕВЫЕ СЛОВА: здравоохранение, медицинское учреждение, медперсонал.

\section{PROVIDE HEALTH CARE SYSTEM OF MEDICAL INSTITUTIONS AND MEDICAL PERSONNEL}

Yu.M. Petrashyk

SHEI "I.Y.Horbachevsky Ternopil State Medical University of the Ministry of Public Health of Ukraine"

Purpose: to identify features of provision of health care medical staff, medical facilities and equipment, to examine the current state and tendencies in health care in the world and in Ukraine.

Materials and methods. In study WHO statistical data on the state of health care in the countries of the world and indicators of healthcare resources in Ukraine has been used; methods of statistical analysis, synthesis and deduction were applied to identify security by medical staff, medical facilities and equipment.

Results. It is established that in health care in Ukraine and the world following tendencies have been observed: reducing of total number of hospital beds with growth intensity of their work; increase quantity of specialized units; growth weight of urgent medical emergency.

Conclusions. The carried out analysis allows predicting the forecast about necessity of those or other kinds of health care and related changes in the health care organization.

KEY WORDS: health care, medical facility, medical staff.

Рукопис надійшов до редакції 11.03.2015 р.

Відомості про автора:

Петрашик Юрій Миколайович - к.філол.н., доц. кафедри соціальної медицини, організації та економіки охорони здоров'я з медичною статистикою ДВНЗ «Тернопільський державний медичний університет імені І. Я. Горбачевського МОЗ України»; тел.: +38(0352)-52-72-33. 